\title{
La linea curva che avvolge lo spazio
}

\author{
Daniela Palomba \\ Simona Scandurra
}

Abstract

Le scale, organismi di connessione, hanno, nei diversi secoli e con differenti linguaggi, rappresentato artefatti chiamati ad assolvere la funzione di collegamento tra i luoghi della dimensione urbana e di quella architettonica, ma hanno anche interpretato il ruolo di artefatti architettonici manifesti di espressioni teoriche e formali.

II tema della scala, nelle sue molteplici forme di espressione, racconta sfide progettuali sia sotto l'aspetto tecnologico che estetico. La lettura di questi 'sistemi di connessione' che rappresentano di sovente degli elementi fortemente rappresentativi delle architetture in cui si avverano, può essere condotta tenendo conto di diversi fattori. Uno tra questi riguarda la tipologia di assetto del vano scala riferito alle matrici geometrico configurative rintracciabili e riconoscibili nella forma degli impianti. Nell'ambito di questo saggio si intende guardare ad alcuni esempi di singolari scale, cellule dell'organismo architettonico, caratterizzate da vani scala cilindrici che possono caratterizzarsi per le differenti curve direttrici, disegnando piante ovate, circolari piuttosto che ellittiche. Nello specifico sono state condotte indagini conoscitive della scala di Palazzo Mannajuolo progettata da Giulio Ulisse Arata all'inizio del XX secolo, per la quale sono stati realizzati rilievi reality based che hanno consentito di individuare e riconoscere i temi e i caratteri figurativi del meraviglioso artefatto.

\section{Parole chiave}

scala elicoidale, Palazzo Mannajuolo, rilievi reality based, analisi configurativa.

Scala elicoidale di Palazzo Mannajuolo. Foto durante le acquisizioni laser e screen della nuvola di punti dal pianerottolo de piano terra.
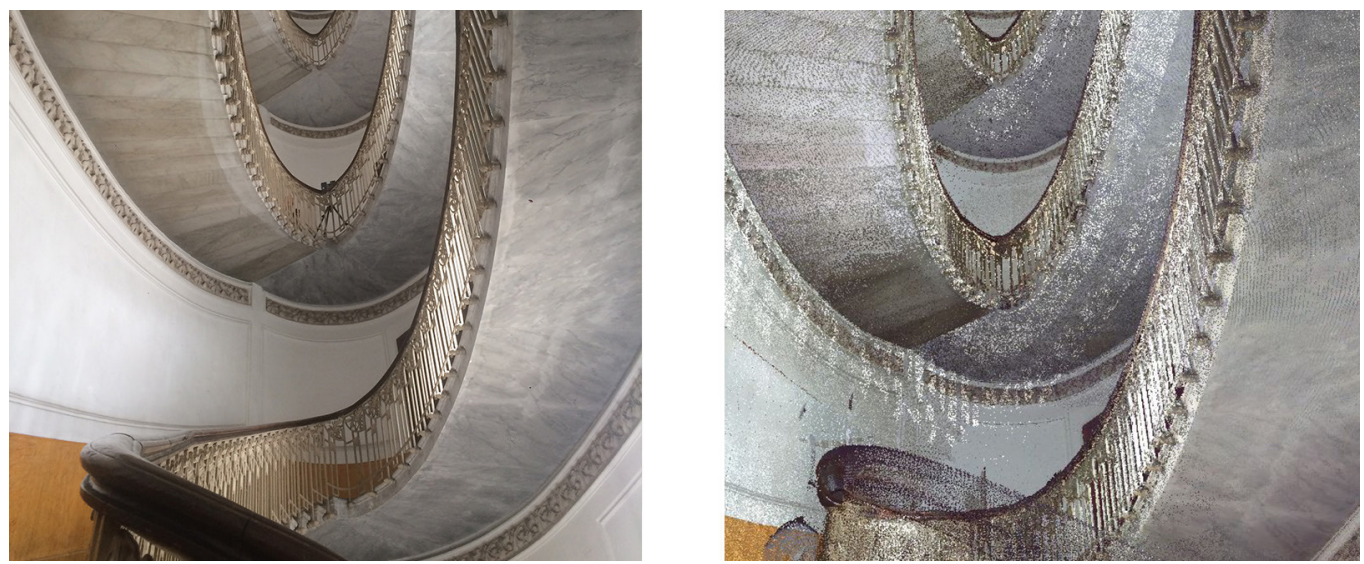


\section{Introduzione}

Le scale, organismi di connessione, hanno, nei diversi secoli e con differenti linguaggi, rappresentato artefatti chiamati ad assolvere la funzione di collegamento tra i luoghi della dimensione urbana e di quella architettonica, ma hanno anche interpretato il ruolo di artefatti architettonici manifesti di espressioni teoriche e formali. Sono innumerevoli gli esempi di progetti di scale che si realizzano quali fenomeni scenografici, monumentali, macchine spettacolari in cui il fruitore è coinvolto in moti ascensionali capaci di generare turbamenti e profonde esperienze percettive e conoscitive. I riti dell'ascesa e della discesa, offrono infatti suggestioni spesso differenti, anche se riferite allo stesso luogo o allo stesso manufatto. I due modi diversi di percorrere la spazialità, ovviamente condizionati anche dalle caratteristiche tipologiche e formali dell'architettura, risentono della velocità dei possibili moti che si generano in questi contesti. L'ascesa, generalmente più lenta, induce l'utente, nella conquista della quota desiderata, a una osservazione più ravvicinata delle rampe e dei gradini. La direzione dello sguardo, quando rivolto verso l'alto, consente di apprezzare anche le soluzioni delle coperture di queste spazialità, quando queste esistono, e di godere di scorci prospettici delle figurazioni degli intradossi delle rampe. Di contro, il moto contrario e dunque in discesa, permette di fruire dei luoghi verosimilmente in tempi più rapidi durante i quali, indipendentemente dalla posizione, la percezione delle componenti architettoniche è ridotta, fin quasi ignorata poiché rilevabile solo indirettamente. L'alzata viene infatti percepita nell'azione del discendere e nel passaggio da un gradino all'altro anche se non può essere vista. Lo sguardo, naturalmente rivolto verso il basso, legge però, con maggiore efficacia, il disegno dell'invaso e la regola che governa la continuità e la dinamicità delle rampe e degli elementi che configurano la struttura connettiva.

Il tema della scala, nelle sue molteplici forme di espressione, racconta sfide progettuali sia sotto l'aspetto tecnologico che estetico. La lettura di questi 'sistemi di connessione' che rappresentano di sovente degli elementi fortemente rappresentativi delle architetture in cui si avverano, può essere condotta tenendo conto di diversi fattori. Uno tra questi riguarda la tipologia di assetto del vano scala e riferita alle matrici geometrico configurative rintracciabili e riconoscibili nella forma degli impianti. Nell'ambito di questo saggio si intende guardare ad alcuni esempi di singolari scale, cellule dell'organismo architettonico, caratterizzate da vani scala cilindrici che possono distinguersi per le differenti curve direttrici, disegnando piante ovate, circolari piuttosto che ellittiche.

Fig. I. Le tavole dei trattati dedicate alle scale. Le prime due da V. Scamozzi (16|5), Dell'idea dell'Architettura Universale - De siti, e forme convenevoli a varie maniere di Scale private ad uso de' tempi nostri \& alcune introdotte dall'Autore, PP. 313,317 \&allictore, pp. 313,317 (1790), I quattro libri dell'architettura, pp.89-91.
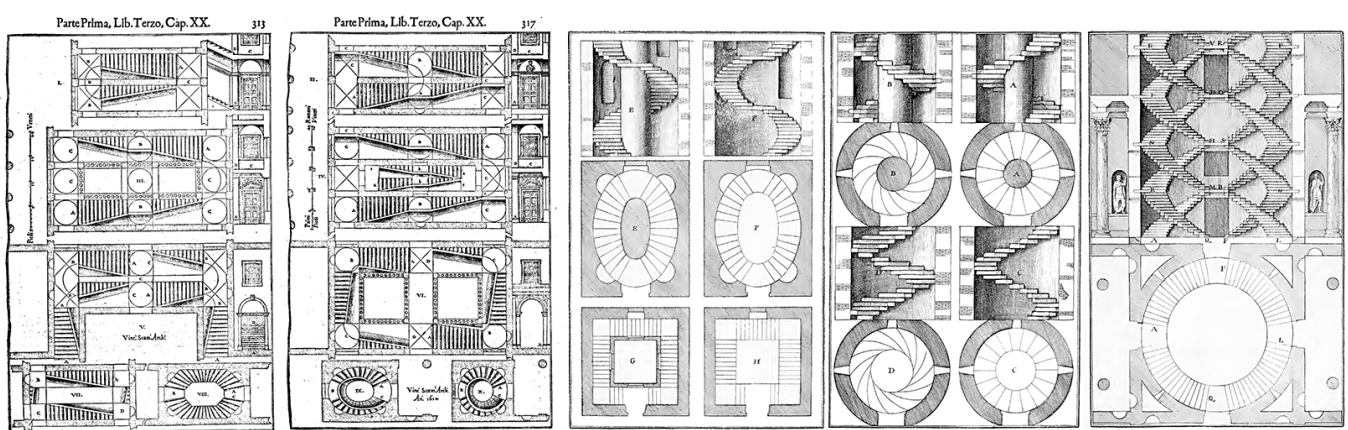

\section{Le fascinazioni della centralità e della linea curva}

"Le linee curve, poiché possono essere variate nel grado di curvatura oltre che nella lunghezza, cominciano con ciò a essere ornamentali. Le linee rette e quelle curve unite, essendo linee composte, variano di più di quelle solo curve e perciò sono un po' più ornamentali. La linea ondeggiante, o linea della bellezza, poiché varia ancor di più, essendo composta di due curve che si contrappongono, diventa ancora più ornamentale e bella nella misura 
in cui la mano compie un movimento animato nel tracciarla a penna o a matita. E la linea serpentina, per il suo ondeggiare e contorcersi allo stesso tempo in modi diversi, conduce l'occhio in modo piacevole lungo il flusso continuo della sua varietà [... ]. E per il suo torcersi in tanti diversi modi si può dire che racchiuda (pur essendo solo una singola linea) diversi volumi"' [Hogarth 200I, p. 67]. Le parole di Hogarth, riferite alle classificazioni delle linee, in modo efficace si prestano a descrivere linee e superfici che generano e disegnano quelle scale a lumaca che offrono esperienze visuali in cui l'occhio è coinvolto in scenari appaganti. La necessità, rivelatasi già nel Rinascimento, di dedicare al 'tema' della scala regole e norme da seguire per la sua rappresentazione e realizzazione ha spinto molteplici trattatisti a dedicarsi a questo argomento [Cirillo 2018, pp. 177-188]. Nel I 615 Vincenzo Scamozzi (fig. I) pubblica Dell'idea dell'Architettura Universale in cui nel capitolo De siti, e forme convenevoli a varie maniere di Scale private ad uso de' tempi nostri, \& alcune introdotte dall'Autore, scrive che "le Scale sono necessarie negli edifici come le vene Cave, e Misseraiche ne' corpi humani, perché sicome queste servono naturalmente, per sumministrare il sangue à tutte le parti del corpo, così e non altrimenti le Scale principali, e secrete incominciando dalle più intime parti [... con un moto artificiale quasi senza isconcio prestano comodità si salire piacevolmente, sino alle parti supreme" [Scamozzi 1615, p. 312]. Scamozzi individua, inoltre, dieci tipologie di scale, tra le quali include anche quelle "a mandola, e le ovali, \& ultimamente le rotonte a chiocciola: le quali possono servire per Scale secrete; così piene, come vuote nel mezo". Attraverso lo studio delle scale è possibile ripercorrere la storia dell'architettura, nonché la storia dei caratteri rappresentativi di una cultura e di una epoca. II tema della scala trova quasi costantemente nella storia dell'architettura napoletana, con espressioni lessicalmente spesso dirompenti, forme espressive attraverso le quali manifestare l'estro dei progettisti e le capacità tecniche delle maestranze. Ne è un esempio la scala a chiocciola quattrocentesca del Maschio Angioino (fig. 2), interamente in piperno e costituita di 158 gradini. Si caratterizza per l'intradosso disegnato da un motivo a voltine, geometricamente riconducibili a sette viti di Saint Gilles accostate, coassiali e generate da circonferenze dai diametri differenti [Paolillo 20 I I, p. 227], che sembrano originate dalla superficie cilindrica che accoglie questo piccolo gioiello costruttivo. L'immagine dal basso rivela una sequenza di eliche e di elicoidi quasi ipnotiche.

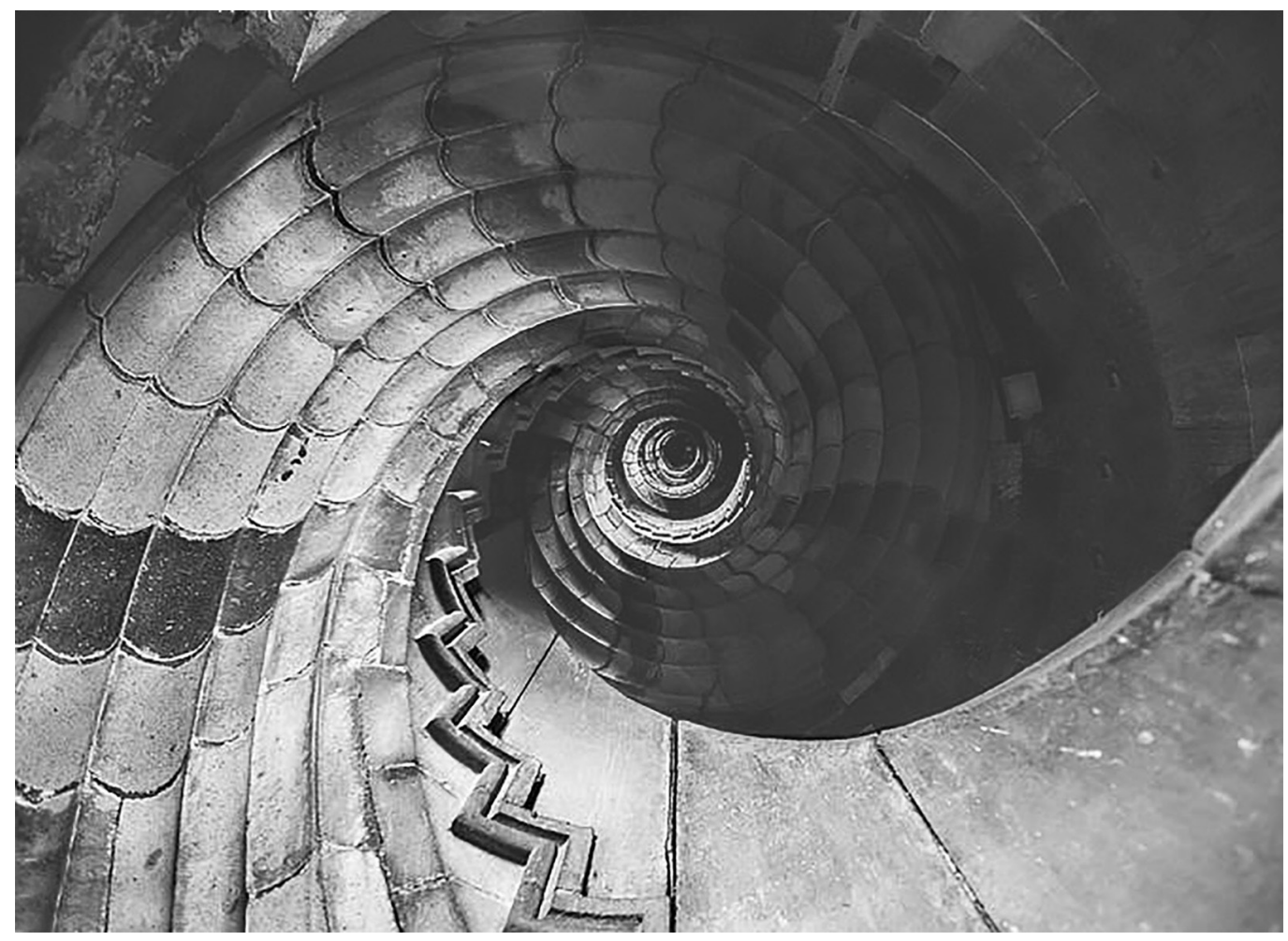


Fig. 3. La scala aperta di Palazzo Mastelloni, Napoli, progetto di Nicola Tagliacozzi Canale e Scala elicoidale di Palazzo Massa, Quartieri Spaznoli Napoli inizi del Spagnoli Napoli, inizi de XX secolo.
È con il secolo XVIII che assistiamo a un modo innovativo di pensare e concepire la scala dei palazzi partenopei che con Sanfelice raggiunge la massima espressione. Ricca è la letteratura dedicata al tema delle scale aperte di matrice sanfeliciana che individua nella già diffusa scala aperta rinascimentale il principio ideativo [Gambardella 1974, Zerlenga 20 I7, Pezone 20।5]. "II barocco è liberazione spaziale, è liberazione mentale dalle regole dei trattatisti, dalle convenzioni, dalla geometria elementare e dalla staticità, è liberazione dalla simmetria e dall'analisi tra spazio interno e spazio esterno" [Zevi 1984, p. 86]. È in questo contesto che è possibile individuare complessi sistemi in cui le rampe si intersecano, seguono traiettorie e percorsi che circoscrivono uno o più pozzi dando luogo, grazie anche ai rampanti diversamente voltati e riccamente decorati, a composizioni ardite, espressioni di leggerezza compositiva [Di Luggo, Catuogno, Paolillo 20I I, p. I2]. Gli impianti sono disegnati da direttrici curvilinee, rettilinee e mistilinee che prefigurano i possibili moti che si generano nel loro sviluppo ascensionale.
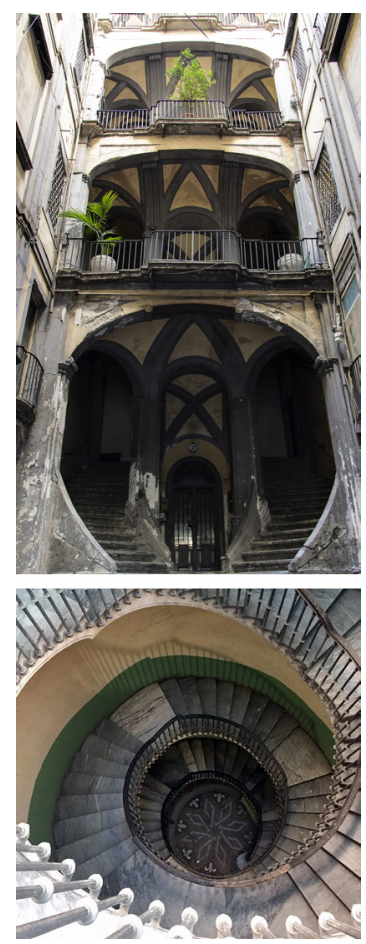

I disegni delle scale circolari, ovate o ellittiche, necessitano di considerazioni circa le possibili soluzioni legate alla distribuzione geometrica dei gradini, alla realizzazione o meno di una struttura portante 'nel mezzo', piuttosto che legata alla presenza e posizione di pianerottoli che interrompono la continuità delle rampe. Un insolito esempio di scala su pianta ovata è quella realizzata per il palazzo Liguoro-Santoro in salita Capodimonte (fig. 4), verosimilmente nella seconda metà del secolo XVIII [I]. È questa una architettura scavata nel tufo che probabilmente ha sfruttato il vuoto di un'antica cavità di estrazione. Si tratta di una scala a matrice ovata che si sviluppa secondo un andamento elicoidale conico rovescio [Cirillo, Zerlenga 2020, pp. 196-207]. Una plausibile giustificazione sulla rastremazione verso il basso del vano scala è da ritracciare in motivi di natura statici. Due le rampe utili a percorrere il passo dell'elica conica, per uno sviluppo totale articolato su cinque rampe. Queste ultime sono intervallate da due pianerottoli, collocati agli estremi dell'asse maggiore dell'ovale e che consentono l'accesso agli appartamenti. Zerlenga, nei suoi studi condotti su questo singolare esempio di ingegno e creatività, individua un probabile coinvolgimento del Sanfelice sia in relazione alla soluzione dei due portali gemelli in facciata ma anche per la possibilità di riconoscere, in questo esempio unico, l'astuzia progettuale e tecnica dell'architetto tra i più creativi del Settecento napoletano. 
Fig. 4. Scala elicoidale di Palazzo Liguoro-Santoro in salita Capodimonte, Napoli.
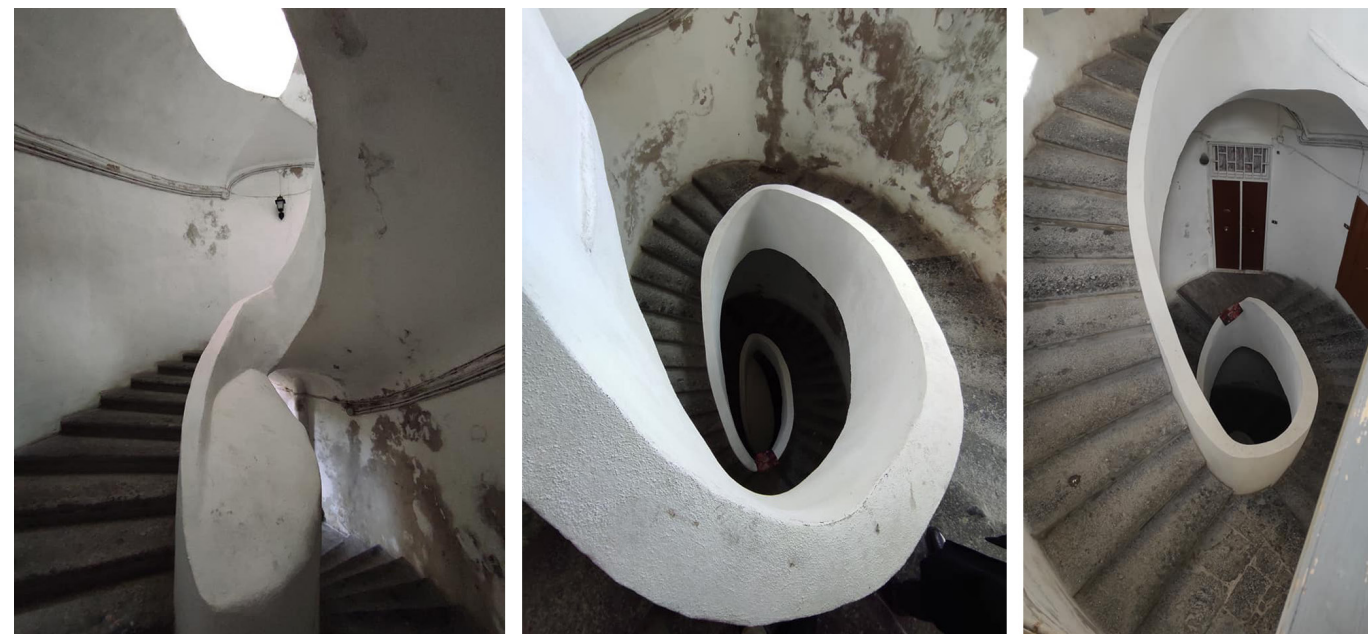

Ma forse la più nota tra le scale del panorama partenopeo, la cui matrice di impianto è riconducibile alle tipologie di scala su pianta curvilinea, è quella realizzata per Palazzo Mannajuolo da Giulio Ulisse Arata e oggetto di studio da parte di diversi autori [De Fusco 1994, Castiglione 2020, Gravagnuolo 1990].

Il linguaggio è quello di un secolo nuovo, sono gli anni in cui impera il gusto floreale. Tra il 1909 e il 191 | l'architetto piacentino concepisce un edificio che risolve la soluzione d'angolo tra via Filangieri e la gradinata Francesco D'Andrea ideando un volume cilindrico, sovrastato da una finta cupola belvedere, che funge da sfondo scenografico per la via Dei Mille, ed elemento di connessione tra i due bracci che compongono l'edificio e che prospettano sulle suddette strade. Due i corpi scala che garantiscono le connessioni verticali e che, simmetricamente disposti rispetto all'androne, si collocano all'estremità del lungo corridoio che disegna il limite del cortile interno. La protagonista indiscussa dell'architettura è la meravigliosa scala dalla matrice ellittica, che si dipana per sette livelli disegnando, nell'alternanza di piani ed elicoidi, un vortice di linee e superfici. Ė la scala che De Fusco descriverà come episodio tecnico e figurativo più interessante nel panorama floreale napoletano [De Fusco 1959, p. I20, De Fusco 1994, p. 45]. L'arditezza tecnica è rintracciabile nella soluzione a sbalzo (fig. 6) proposta per i gradini a massello in marmo sagomato [Gravagnuolo B., Gra-
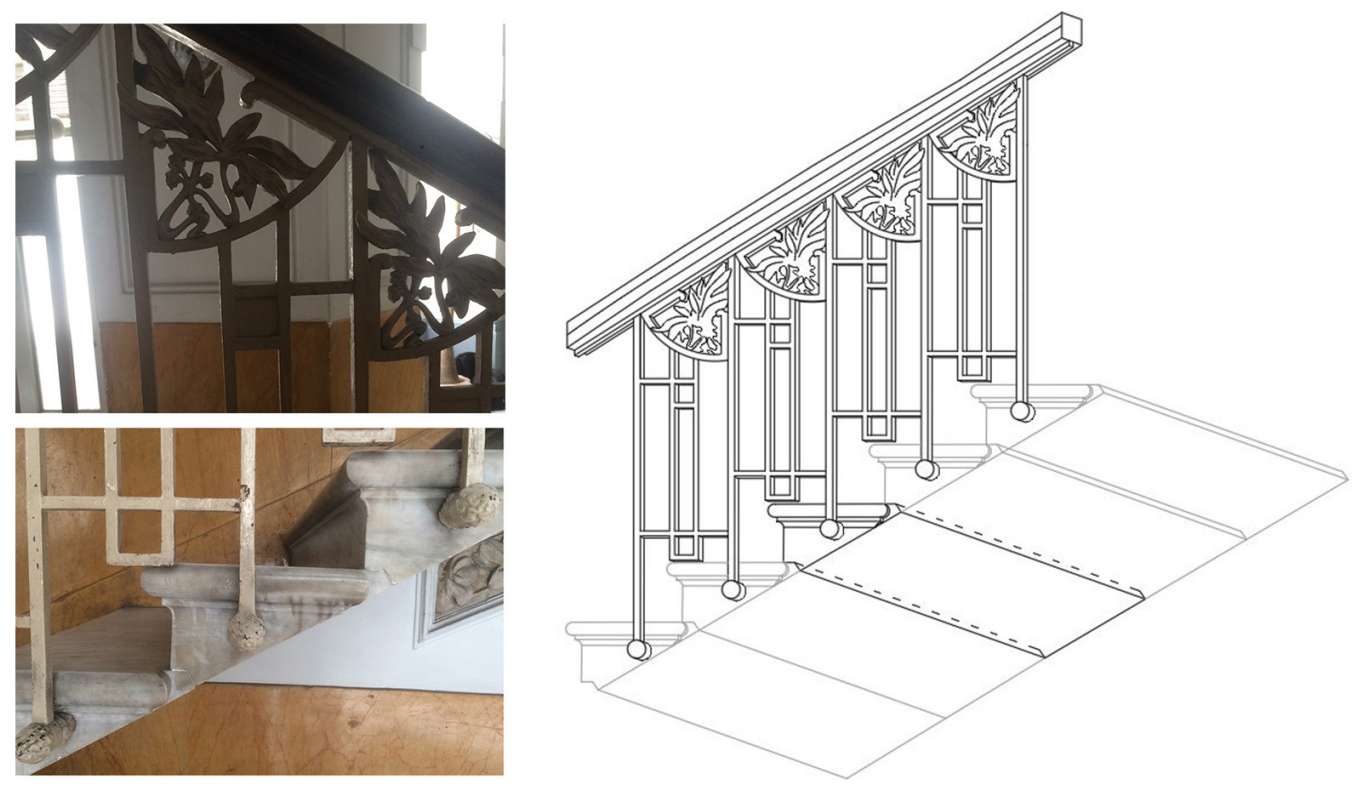
vagnuolo C., p. 8I]. II singolo gradino è privato quasi totalmente dello spessore della soletta e si incastra all'elemento che lo segue mediante superfici concavo-convesse che seguono la logica dell'incastro maschio-femmina. L'intradosso continuo della scala, anch'esso interamente rivestito in marmo, si caratterizza per la superficie geometricamente riconducibile a un elicoide rigato. La genesi geometrica della superficie di rototraslazione si rivela attraverso la retta d'intersezione tra i gradini, il segmento orizzontale ortogonale all'asse di rotazione, che può considerarsi quale retta generatrice dell'elicoide a piano direttore.

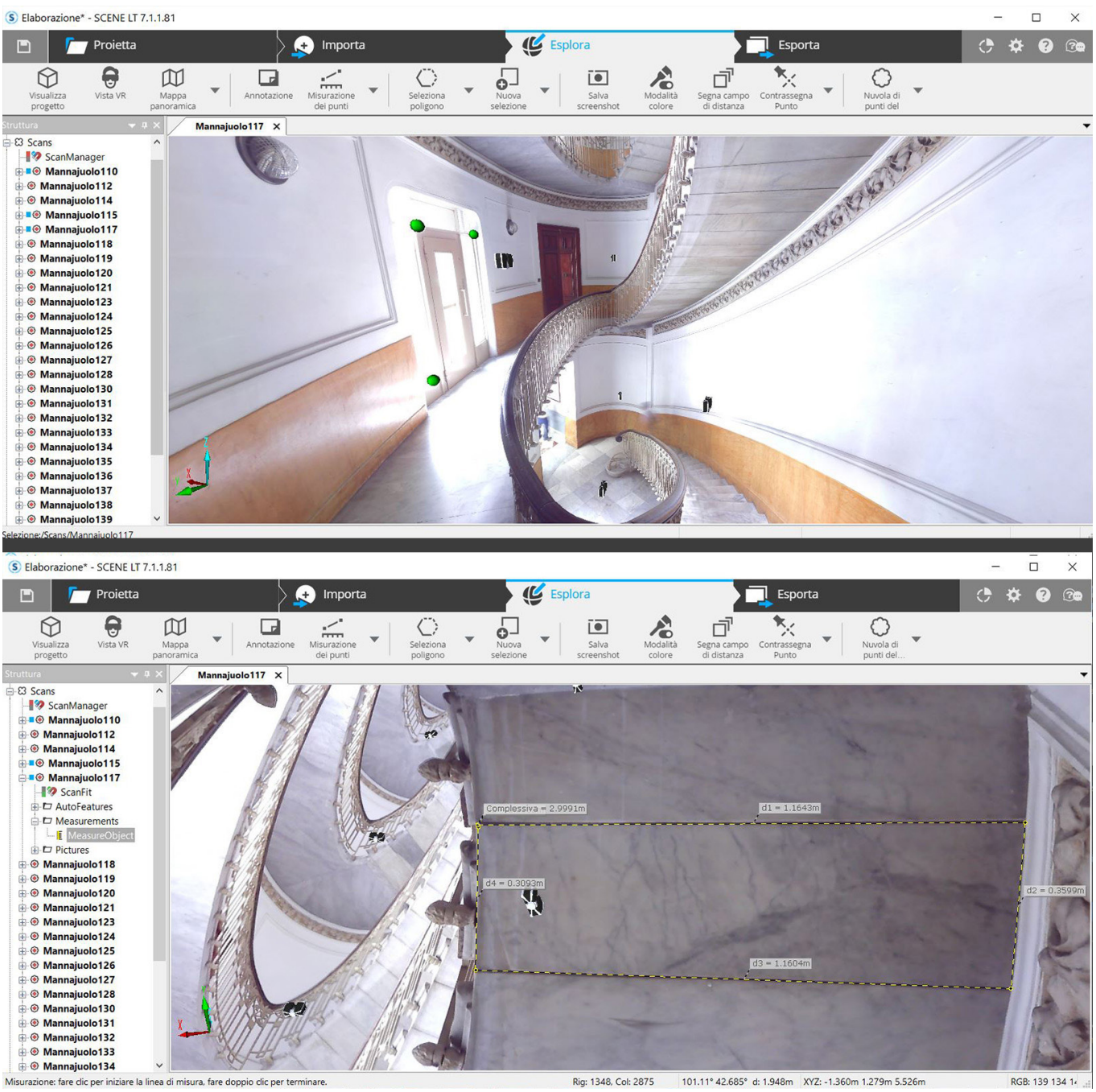

\section{Un caso studio nel contesto napoletano}

II presente contributo fa riferimento a una campagna di rilievo eseguita nel 20 I 6 i cui dati sono stati riprocessati ai fini dell'approfondimento di ulteriori aspetti compositivi e costruttivi [2]. In considerazione della particolare conformazione spaziale e degli elementi di cui si compone la scala di Palazzo Mannajuolo, si è scelto di procedere con una campagna di rilievo reality based. In particolare, si è preferito prediligere un sistema ottico attivo progettando il percorso delle stazioni laser scanner affınché fossero minimizzate il più possibile le zone d'ombra. La scala, infatti, sebbene presenti un pozzo centrale libero da pilastri ed esteso per tutti i sette livelli, si compone di rampe e pianerottoli protetti da una ringhiera in 
Fig. 7. Scala elicoidale di Palazzo Mannajuolo. Esploso assonometrico della nuvola di punti lase scanner.

Fig. 8. Scala elicoidale di Palazzo Mannajuolo. Analisi della composizione geometrica della pianta.

Fig. 9. Scala elicoidale di Palazzo Mannajuolo. composte da 25 pedate composte da 25 pedate interpiano sono tett

Fig. 10. Scala elicoidale di Palazzo Mannajuolo. Sezione longitudinale e sezione.
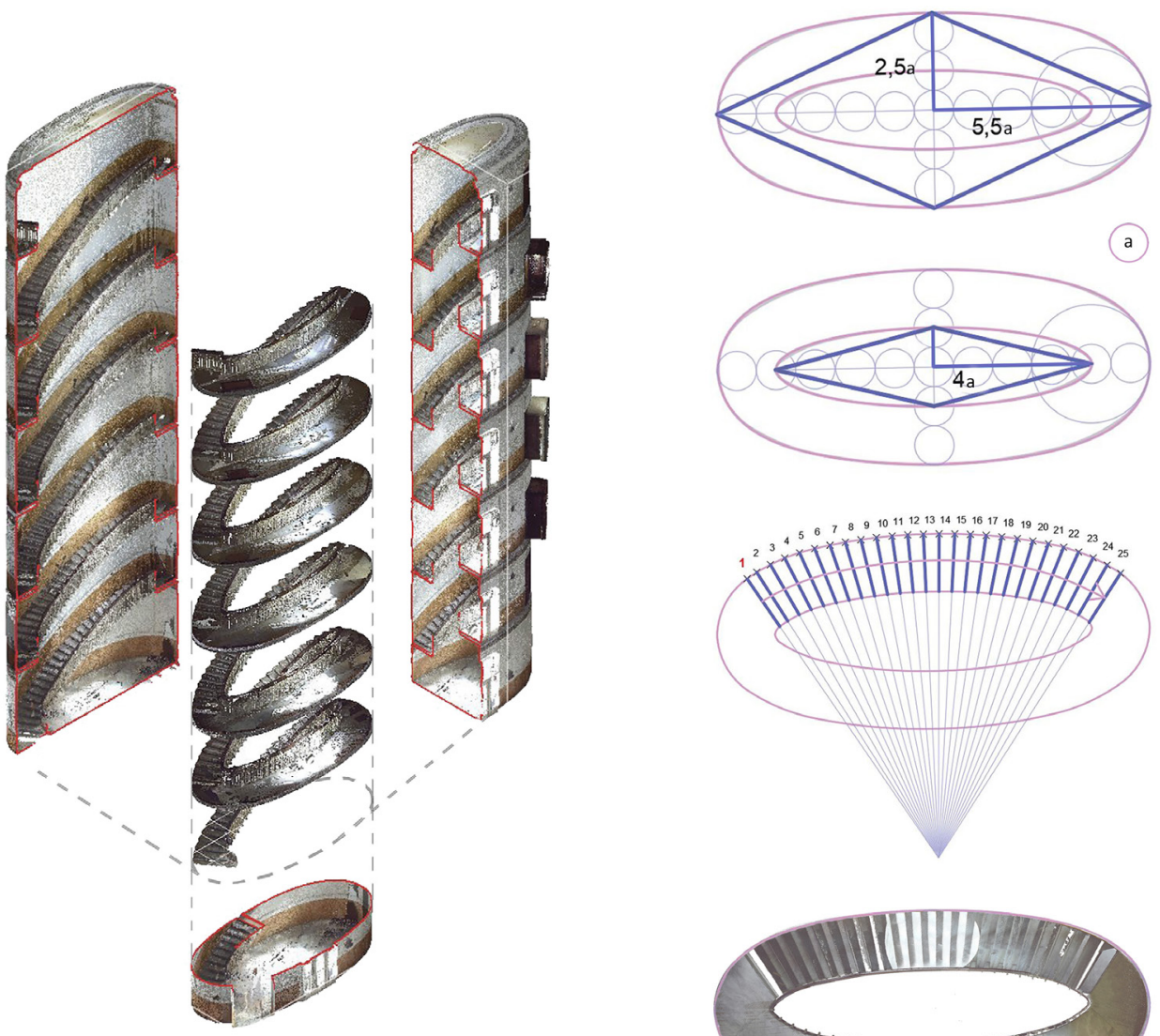

(a)
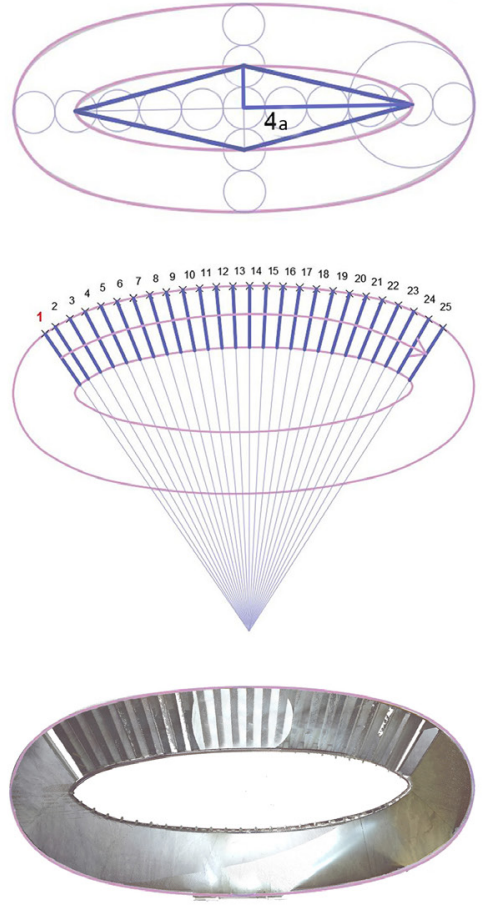
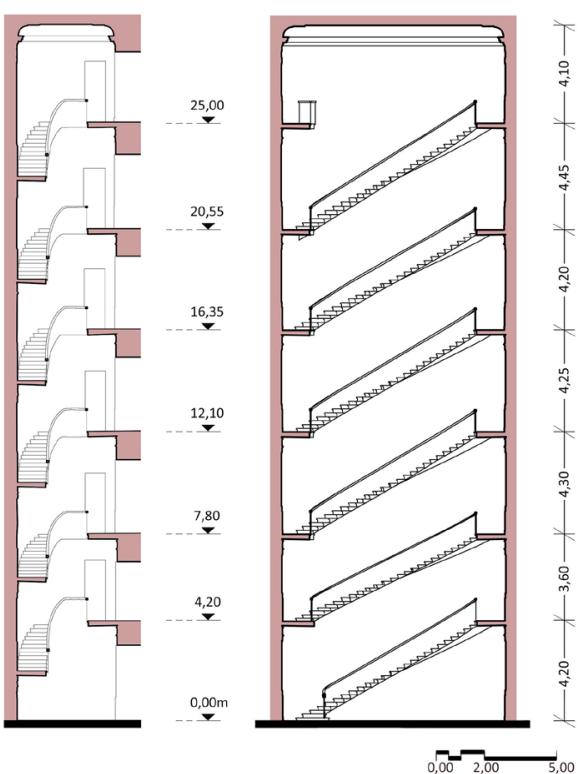
ghisa lavorata con un motivo floreale tipico del linguaggio liberty. II numero e la posizione delle scansioni sono stati dunque pensati affinché la proiezione della ringhiera non creasse disturbo nell'acquisizione delle alzate e delle pedate della rampa.

II rilievo è stato effettuato con un Laser scanner Faro Focus 3D s I 20 in dotazione al Laboratorio TIR del Dipartimento di Architettura dell'Università Federico II di Napoli. Sono state eseguite ventisette scansioni totali, impostando un passo tra i punti di $6,136 \mathrm{~mm}$ a $10 \mathrm{~m}$. I punti di stazione sono stati scelti percorrendo la scala dal basso verso l'alto. In particolare, sono state eseguite due acquisizioni al piano terra, tre per ogni rampa (inizio, centro e fine), una al centro di ogni pianerottolo e una alla fine dell'ultimo pianerottolo (per una migliore acquisizione della copertura).

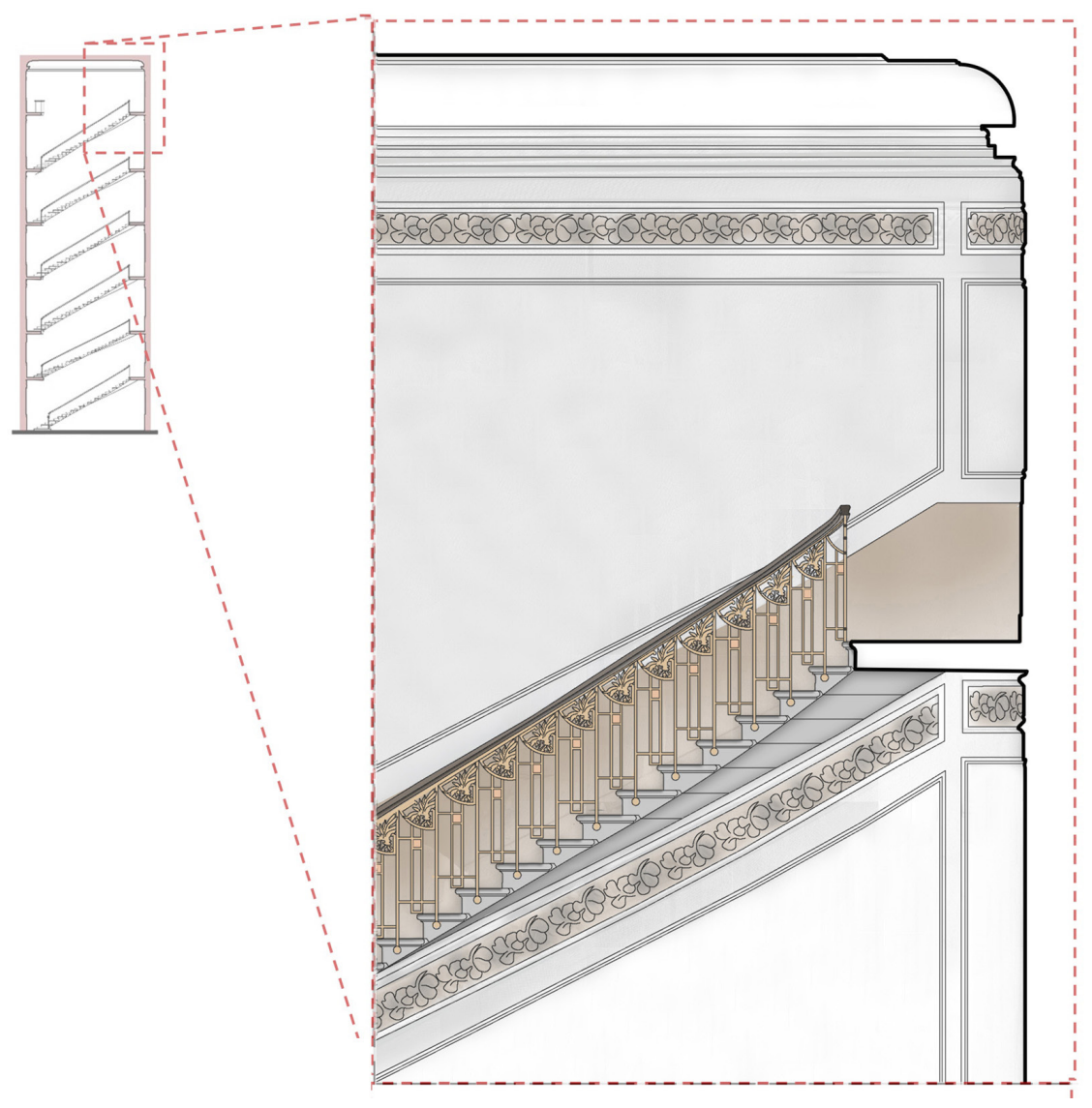

Al fine di agevolare le fasi di post-processing, realizzato con software proprietario Faro SCENE, lungo il percorso sono stati distribuiti target sferici e target a scacchiere utili ad agevolare le fasi di allineamento tra le varie scan position (fig. 6).

La campagna di rilievo laser scanner ha permesso di ottenere un clone digitale tridimensionale dell'opera di Arata sotto forma di nuvola di punti (fig. 7).

Dall'analisi di tale dato sono emerse una serie di ambiguità compositive non percepibili a prima vista, che suggeriscono alcune riflessioni nel rapporto tra realtà percepita e realtà costruita.

Da una prima lettura la scala si compone di 6 rampe alternate a pianerottoli che si ripetono sovrapposte e apparentemente di uguale dimensione, descrivendo l'invaso cilindrico caratterizzato da una curva direttrice ellittica. II ridisegno e l'acquisizione dei dati morfometrici ricavati direttamente sulla nuvola di punti ha reso più chiari i riferimenti geometrici della composizione di base, evidenziandone coerenze ed eccezioni. 
La proiezione piana dell'invaso si caratterizza per la curva direttrice del cilindro assimilabile a una ellisse i cui assi sono in rapporto | |:5. Analizzando la forma si è infatti riscontrata una relazione proporzionale tra i due assi individuata dalla ripetizione di un modulo indicato in figura 8 con la lettera a (fig. 8). La curva che disegna il limite interno della rampa e del pianerottolo può invece ricavarsi come offset della prima ellisse, ottenuta quale conseguenza della scelta di mantenere costante la larghezza delle rampe e dei pianerottoli, pari a circa I,25 m.

La distribuzione dei gradini segue una geometria a raggiera il cui centro di rotazione si individua lungo un asse verticale esterno al cilindro. I segmenti che disegnano le pedate in pianta convergono infatti tutti verso un unico centro e mantengono una rotazione angolare costante pari a circa $2.7^{\circ}$, a meno della prima pedata che si differenzia, seppur di poco, dalle altre ampiezze di pedata, sia rispetto alla specifica rampa di appartenenza, sia rispetto alle prime pedate delle altre rampe.

Dall'analisi del dato 3D è emerso che, sebbene le rampe siano tutte composte da 25 pedate, l'altezza di interpiano ha una variazione relativa che va da $10 \mathrm{~cm}$ a $85 \mathrm{~cm}$, solo in parte attribuibile a deformazioni naturali e difetti di costruzione. In tal senso, infatti, possono essere individuate almeno tre tipi di rampe dall'uguale ingombro planimetrico e dal differente sviluppo altimetrico, che si dispongono verticalmente secondo un ritmo A-B-A-A-A-C (fig. 9). Le differenze si riscontrano in variazioni relativamente minime tra le alzate dei singoli gradini, di per sé trascurabili ma che nel totale rendono possibile mantenere costanti il numero e la dimensione delle pedate (fig. 10).

Le figurazioni realizzate diventano strumento mediante il quale tradurre ed interpretare i caratteri e i principi fondativi della composizione. Queste stabiliscono una connessione tra il modello reale ed il modello grafico, mediante il quale esprimere le operazioni culturali proprie della rappresentazione, che si avverano in una operazione di sintesi tra segni e discretizzazione della realtà fisica (fig. I I).

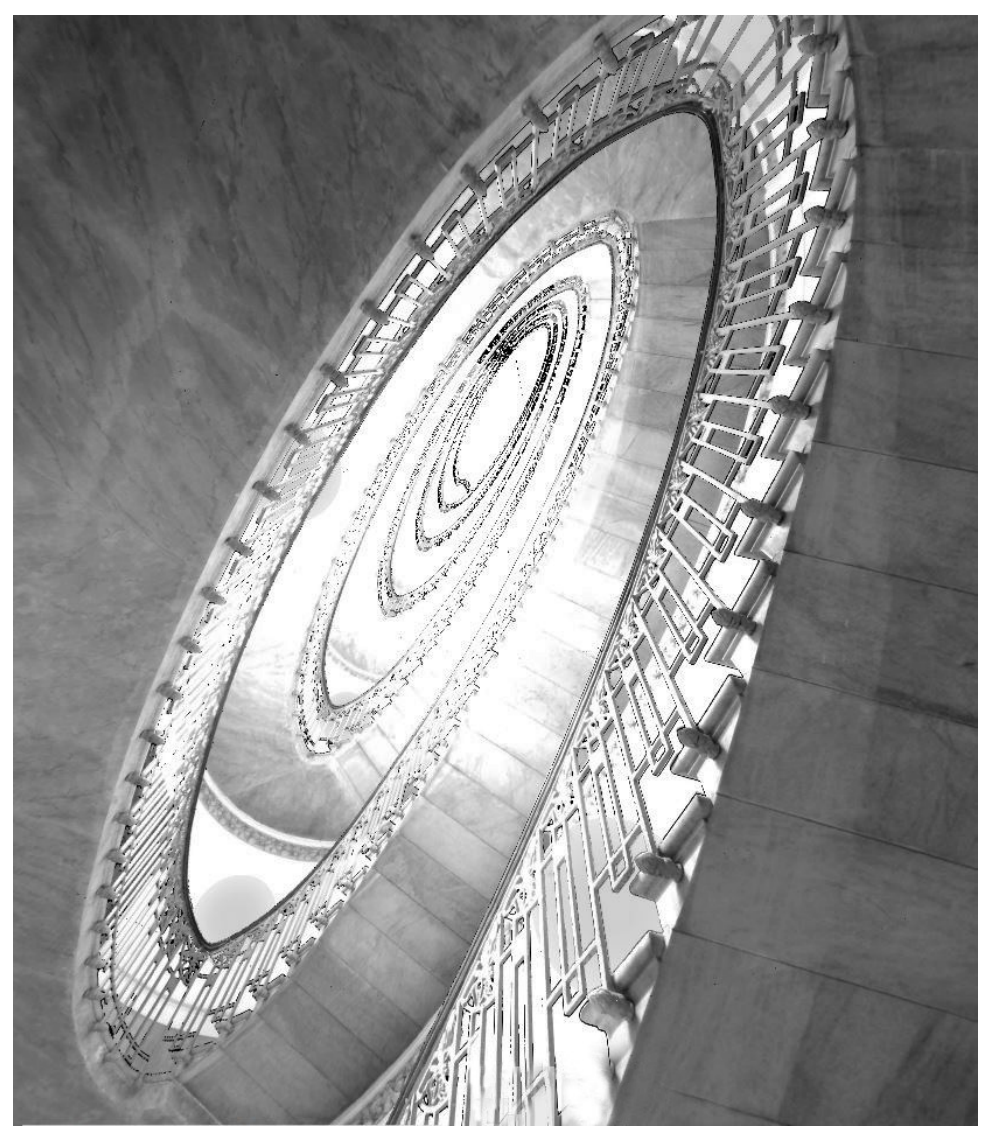




\section{Conclusione}

La scala può considerarsi come un "archetipo sempre inedito, un'invariante che si rinnova continuamente, una forma dinamica attraverso la quale si concretizza il rapporto tra le qualità del tempo e le qualità dell'esperienza" [Marcoaldi 20I5, p. 13]. La scala di palazzo Mannajuolo interpreta appieno questo concetto. Un organismo che manifesta ed esalta le qualità lessicali del suo tempo e si propone quale sperimentazione in grado di mettere in scena una esperienza che coinvolge pienamente chi la percorre. La scala assume un ruolo fondamentale divenendo vera protagonista dell'organismo architettonico in cui assi direzionali e forze ascensionali sono gli strumenti mediante i quali concepire la spazialità ricca di suggestioni e seducenti soluzioni (fig. 12).

\section{Note}

[I] Al 1746 risalgono i lavori di rifacimento del Palazzo, in sostituzione di quello crollato a causa delle vetuste condizioni.

[2] La campagna di rilievo è stata condotta dagli architetti Raffaele Catuogno, Simona Scandurra e Giulia Piccinin e ha dato esito al contributo De Rosa, A., D'Acunto, G., Piccinin, G. (2019). La vertigine dello sguardo: la scala elicoidale di Palazzo Mannajuolo In Anfione e Zeto n. 29, pp. 166-I7|.

\section{Riferimenti bibliografici}

Castagnaro A., Castiglione F. (2020). Giuseppe e Ugo Mannajuolo. Napoli: Editori Paparo.

Cirillo V. (20 I8). La rappresentazione della scala nella trattatistica italiana dal XVI al XVIII secolo. In diségno, vol. I, n. 3, pp. I77- I88. Cirillo V., Zerlenga O. (2020). Entre arquitectura y geometría. Un ejemplo de escalera oval en la toba napolitana. In EGA Expresión Gráfica Arquitectónica, [S.I.], v. 25, n. 39, pp. 196-207.

De Fusco R. (1959). II floreale a Napoli. Napoli: Edizioni Scientifiche Italiane.

De Fusco R. (1994). Napoli nel Novecento. Napoli: Electa Napoli.

di Luggo A., Catuogno R., Paolillo A. (20I I). Palazzi Napoletani. Itinerari grafici e percorsi interpretativi nel rilievo dell'architettura. Napoli: Giannini Editore.

Gambardella A. (1974). Ferdinando Sanfelice architetto. Napoli.

Gravagnuolo B., Gravagnuolo G. (1990). Chiaia. Napoli: Electa Napoli.

Hogarth W. (200 I). L'analisi della Bellezza. Milano: Aesthetica.

Marcoaldi P. (20I5). 7 tipi di scale. La dimensione urbana della scala tra riti, spazialità e tempo. Roma: Aracne editrice.

Pezone M. G. (20I5). Geometria e arditezza tecnica nelle scale napoletane del Settecento a matrice poligonale. In G. Amirante, M. G. Pezone (a cura di). Tra Napoli e Spagna. Città storica architetti e architetture tra XVI e XVIII secolo. Napoli: Grimaldi Editore. Rosi R. (20 I2). Palazzo Mannajuolo. Napoli: Paparo Edizioni.

Scalvini M. L., Mangone F. (1990). Arata a Napoli tra liberty e neoeclettismo. Napoli: Electa Editore.

Scamozzi V. (1615). Dell'idea dell'Architettura Universale, parte prima, libro terzo. Venezia.

Zerlenga O. (20 I7). Disegnare le ragioni dello spazio costruito. Le scale aperte del '700 napoletano. In diségno, n. I, pp. 45-56. Zevi B. (1994). Saper vedere l'architettura.Torino: Giulio Einaudi Editore.

\section{Autori}

Daniela Palomba, Università degli Studi di Napoli “Federico II", daniela.palomba@unina.it Simona Scandurra, Università degli Studi di Napoli “Federico II", simona.scandurra@unina.it 


\title{
The Curved Line that Envelops the Space
}

\author{
Daniela Palomba \\ Simona Scandurra
}

\section{Abstract}

Stairs are connecting organisms that have represented over the centuries and with different languages artefacts often called upon to connect the urban and architectural dimensions of places, while also interpreting the role of architectural artefacts that manifest theoretical and formal expressions. The theme of the staircase, in its many forms of expression, recounts design challenges from both a technological and aesthetic point of view. The reading of these 'connection systems' which are often highly representative elements of the architectures in which they occur, can be carried out taking into account various factors. One of these regards the type of layout of the stairwell referred to the configurative geometric matrices that can be traced and recognised in the shape of the systems. This essay intends to look at some examples of singular staircases, cells of the architectural organism, with by cylindrical stairwells that can be characterized by the different directing curves, drawing ovate, circular plans rather than elliptical ones. Specifically, cognitive studies were carried out on the staircase of Palazzo Mannajuolo designed by Giulio Ulisse Arata at the beginning of the twentieth century, along with reality-based surveys that made it possible to identify and recognise the themes and figurative characteristics of this wonderful artefact.

\section{Keywords}

helical staircase, Palazzo Mannajuolo, reality-based surveys, configurative analysis.
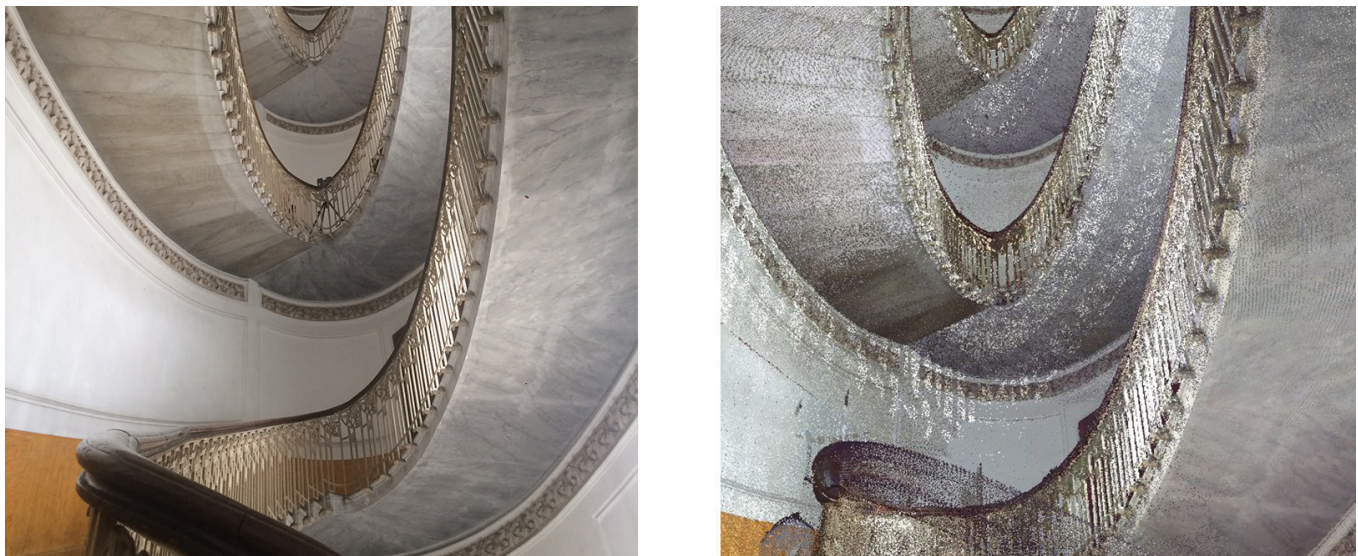


\section{Introduction}

Stairs are connecting organisms that have represented over the centuries and with different languages artefacts often called upon to connect the urban and architectural dimensions of places, while also interpreting the role of architectural artefacts that manifest theoretical and formal expressions. There are countless examples of staircases that are scenographic, monumental phenomena, spectacular machines in which the user is involved in upward motions capable of generating disturbances, along with profound perceptual and cognitive experiences. The rites of ascending and descending often offer different suggestions, even if they refer to the same place or to the same artefact.The two different ways of traversing spatiality, obviously conditioned by the typological and formal characteristics of the architecture, are affected by the speed of the possible movements that are generated in these contexts. The ascent, generally slower, leads the user, in conquering the desired altitude, to a closer observation of the ramps and steps. The direction of the gaze, when turned upwards, also allows to appreciate the solutions of the roofs of these spaces, when these exist, and to enjoy perspective glimpses of the figures of the soffits of the ramps. On the other hand, the opposite and therefore downward motion allows to enjoy the places probably in a shorter time during which, regardless of the position, the perception of the architectural components is reduced, almost ignored since it can only be detected indirectly. The rise is perceived in the action of descending and in the passage from one step to another even if it cannot be seen. The gaze, naturally turned downwards, however, more effectively reads the design of the stairwell as well as the rule that governs the continuity and dynamism of the ramps and the elements that configure the connective structure.

The theme of the staircase, in its many forms of expression, recounts design challenges from both a technological and aesthetic point of view. The reading of these 'connection systems' which are often highly representative elements of the architectures in which they occur, can be carried out taking into account various factors. One of these regards the type of layout of the stairwell referred to the configurative geometric matrices that can be traced and recognised in the shape of the systems. This essay intends to look at some examples of singular staircases, cells of the architectural organism, with cylindrical stairwells that can be characterised by the different directing curves, drawing ovate, circular plans rather than elliptical ones.

Fig. I. The tables of the treatises dedicated to staircases. The first two from V. Scamozzi (1615), Dell'idea dell'Architettura Universale - De siti, e forme convenevoli a varie maniere di Scale private ad uso de' tempi nostri, \& alcune introdotte dall'Au tore introdotte dall Au- 313,317 . THe tore, pp. $313,317 . \mathrm{THe}$ thers from A. Palladio dell'architettura, pp.89-9!.
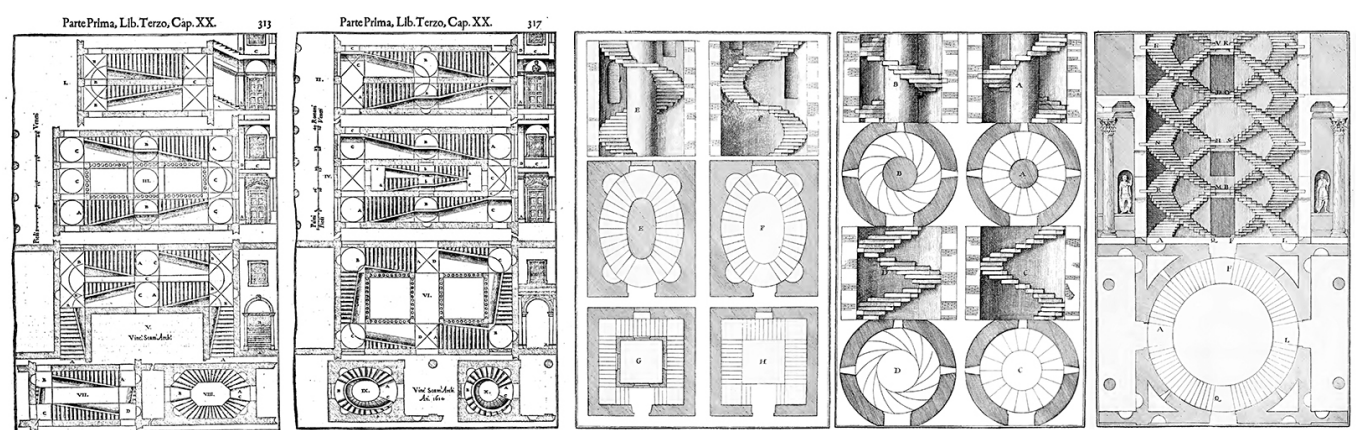

\section{The fascinations of centrality and the 'curved line'}

"Curved lines, since they can be varied in the degree of curvature as well as in length, thus begin to be ornamental. Straight lines and joined curves, being compound lines, vary more than just curved ones and therefore are a little more ornamental. The undulating line, or line of beauty, since it varies even more, being composed of two opposing curves, becomes even more ornamental and beautiful in the measure in which the hand makes an animated 
movement in tracing it in pen or pencil. And the serpentine line, due to its swaying and twisting at the same time in different ways, leads the eye in a pleasant way along the continuous flow of its variety [...]. And due to its twisting in so many different ways, it can be said that it encloses (even if it is only a single line) different volumes [Hogarth 200I, p. 67]'. Hogarth's words, referring to the classifications of lines, effectively lend themselves to describing lines and surfaces that generate and draw those spiral stairs that offer visual experiences in which the eye is involved in satisfying scenarios. The need, already revealed in the Renaissance, to devote rules and norms to be followed for the representation and implementation to the 'theme' of the staircase has prompted many writers to deal with this topic [Cirillo 20 I8, pp. 177- I 88]. In 1615,Vincenzo Scamozzi (fig. I) published Dell'idea dell'Architettura Universale in cui nel capitolo De siti, e forme convenevoli a varie maniere di Scale private ad uso de' tempi nostri, \& alcune introdotte dall'Autore, and writes that "le Scale sono necessarie negli edifici come le vene Cave, e Misseraiche ne' corpi humani, perché sicome queste servono naturalmente, per sumministrare il sangue à tutte le parti del corpo, così e non altrimenti le Scale principali, e secrete incominciando dalle più intime parti [...] con un moto artificiale quasi senza isconcio prestano comodità si salire piacevolmente, sino alle parti supreme" (Stairs are necessary in buildings like veins in human bodies, since they naturally serve to administer blood to all parts of the body, just like the main stairs, with the secret one leading to the most intimate parts [...] with an artificial motion almost without shaking they lend comfort to pleasantly ascend, up to the higher parts) [Scamozzi I 6I 5, p. $3 \mid$ 2]. Scamozzi also identifies ten types of staircase, among which he also includes the "a mandola, e le ovali, \& ultimamente le rotonte a chiocciola: le quali possono servire per Scale secrete; così piene, come vuote nel mezo" ("mandola" and oval ones and lastly the spiral round one, which can be used for secret stairs; so full, as empty in the middle").

Through the study of staircases, it is possible to retrace the history of architecture, as well as the history of the representative characteristics of a culture and era. The theme of the staircase is constant in the history of Neapolitan architecture, with lexically often disruptive expressions, expressive forms through which to manifest the creativity of the designers and the technical skills of the workers. An example of this is the 15th century spiral staircase of the Maschio Angioino (fig. 2), entirely in piperno and consisting of I 58 steps which is charac-

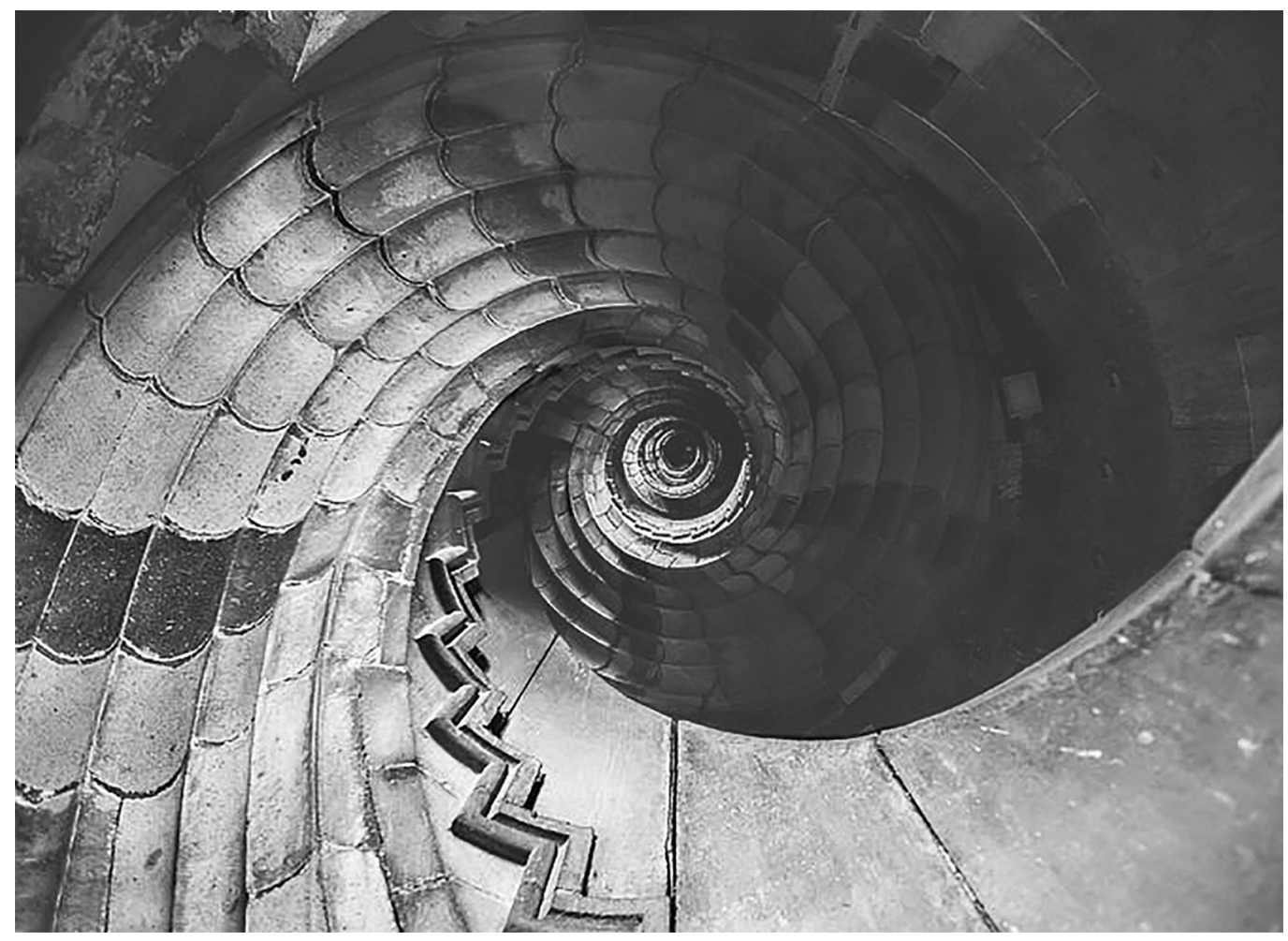


Fig. 3.The open staircase of Palazzo Mastelloni, Nicola Tagliacozzi Canal and helicoidal staircase of Palazzo Massa, Quartieri Palazzo Massa, Quartier $20^{\text {th }}$ Century. terized by the intrados with a vaulted motif, geometrically attributable to seven juxtaposed Saint Gilles vines, coaxial and generated by circumferences of different diameters [Paolillo 20I I, p. 227], which seem to originate from the cylindrical surface that houses this small constructive jewel. The image from below reveals an almost hypnotic sequence of helices and helicoids.

The 18th century sees an innovative way of thinking and conceiving the staircase of Neapolitan buildings that with Sanfelice reaches its maximum expression. There is a wealth of literature dedicated to the theme of open Sanfelician staircases which identifies the ideation principle in the already widespread Renaissance open staircase [Gambardella 1974; Zerlenga 2017; Pezone 2015]. "The Baroque is spatial liberation, it is mental liberation from the rules of the treatise writers, from conventions, from elementary and static geometry, it is liberation from symmetry and analysis between internal and external space [Zevi 1984, p. 86]. It is in this context that it is possible to identify complex systems in which the ramps in-
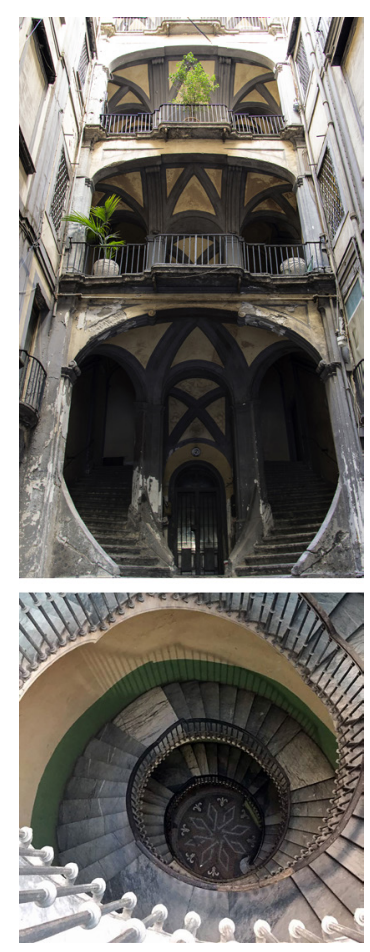

tersect, follow trajectories and paths that circumscribe one or more wells giving rise, thanks also to the differently vaulted and richly decorated rampants, to daring compositions, expressions of compositional lightness [Di Luggo, Catuogno, Paolillo 20 I I, p. I2]. The systems are designed by curvilinear, rectilinear and mixtilinear lines that foreshadow the possible motions that are generated in their upward development.

The drawings of circular, ovate or elliptical staircases require considering the possible solutions related to the geometric distribution of the steps, to the realization or not of a supporting structure 'in the middle', rather than linked to the presence and position of landings that interrupt the continuity of the ramps. An unusual example of an oval-shaped staircase is the one built for the Liguoro-Santoro building on Salita Capodimonte (fig. 4), probably in the second half of the I8th century [I]. It is carved into the tuff, which probably exploited the void of an ancient extraction cavity. It is an ovate matrix staircase that develops according to an inverted conical helical pattern [Cirillo, Zerlenga 2020, pp. 196-207]. A plausible justification on the downward tapering of the stairwell is to be traced back to static motifs. There are two useful ramps to cover the pitch of the conical propeller, for a total development articulated on five ramps. The latter are interspersed with two landings, located at the ends of the major axis of the oval and which allow access to the apartments. Zerlenga, in her 

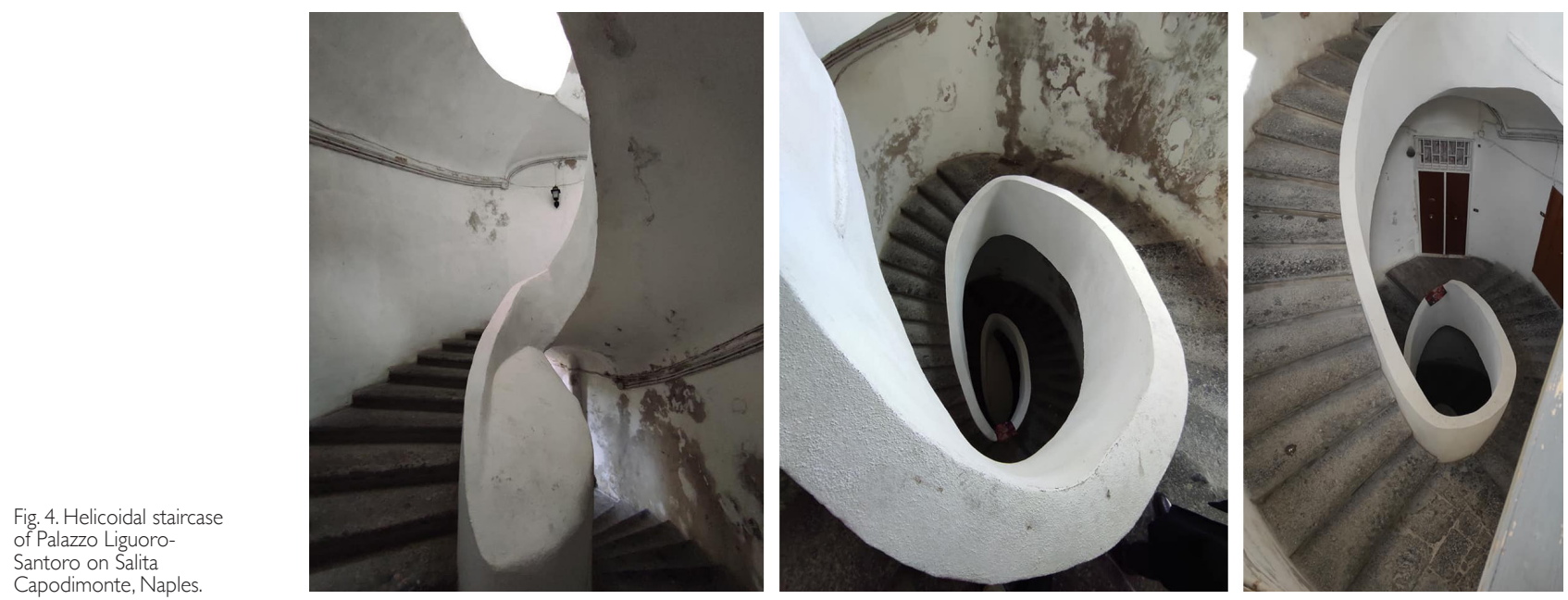

studies carried out on this singular example of ingenuity and creativity, identifies a probable involvement of Sanfelice both in relation to the solution of the two twin portals on the facade but also recognising, in this unique example, the cunning design and technique of the most creative 18th century Neapolitan architect.

The most well-known Neapolitan staircase, whose layout is attributable to the types of stairs on a curvilinear plan, is the one created for Palazzo Mannajuolo by Giulio Ulisse Arata and object of study by various authors [De Fusco 1994, Castiglione 2020, Gravagnuolo 1990]. The language is that of a new century, these are the years in which floral taste reigns. Between 1909 and 1911, the architect from Piacenza conceived a building that solves the corner solution between via Filangieri and the Gradinata Francesco D'Andrea by designing a cylindrical volume, surmounted by a fake belvedere dome, which acts as a scenographic background for via Dei Mille, and an element of connection between the two arms that make up the building and overlook the aforementioned streets. There are two stairwells that ensure vertical connections and which, symmetrically arranged with respect to the entrance hall, are located at the end of the long corridor that draws the boundary of the internal courtyard. The undisputed protagonist of the architecture is the marvellous staircase with an elliptical matrix, which unravels over seven levels, drawing a vortex of lines and surfaces
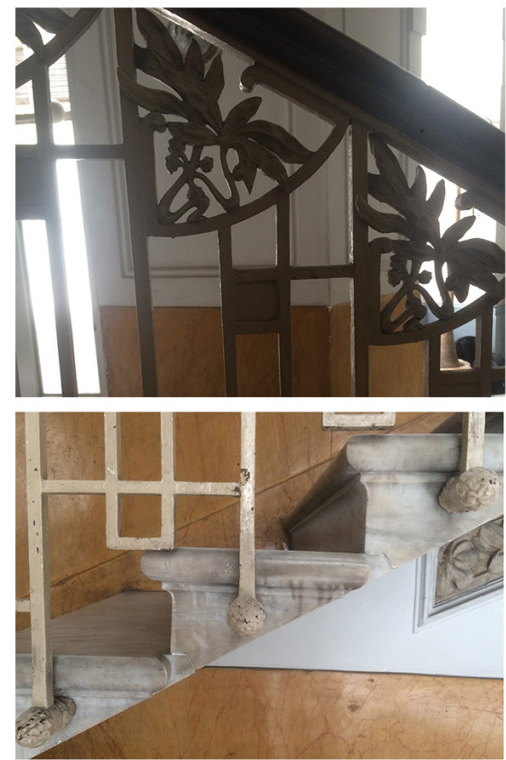

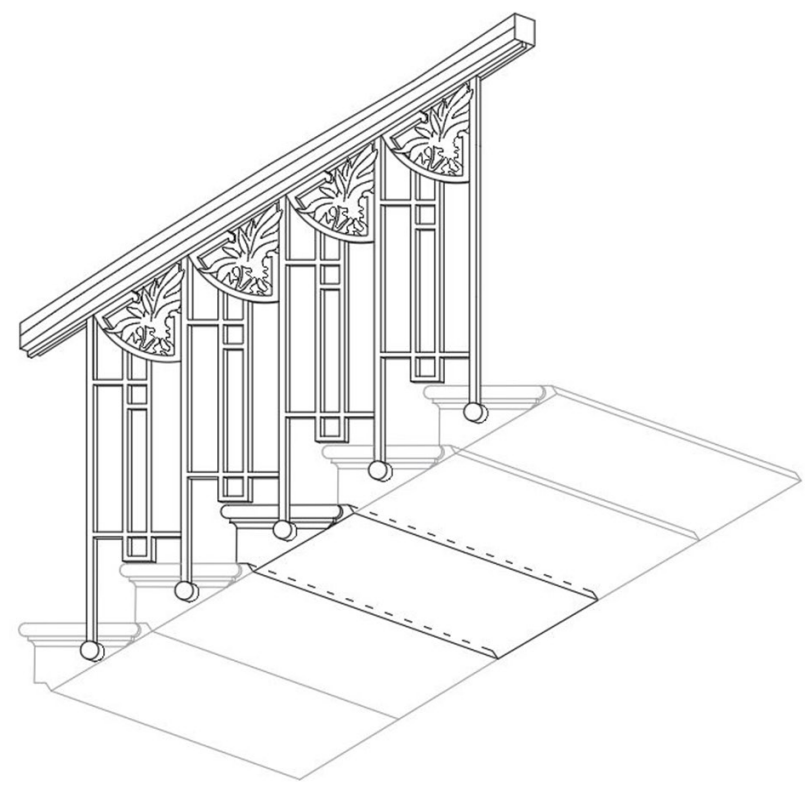


in the alternation of planes and helicoids. It is the staircase that De Fusco will describe as the most interesting technical and figurative episode in the Neapolitan floral scene [De Fusco 1959, p. 120, De Fusco 1994, p. 45]. The technical boldness can be traced in the cantilevered solution (fig. 6) proposed for the solid shaped marble [Gravagnuolo B., Gravagnuolo C., 1990, p. 81 ]. The single step is almost totally deprived of the thickness of the slab and fits into the element that follows it by means of concave-convex surfaces that follow the logic of the tongue-and-groove joint. The continuous intrados of the staircase, which is also entirely covered in marble, is characterized by a geometrically referable surface to a ribbed helicoid. The geometric genesis of the roto-translation surface is revealed through the intersection line between the steps, the horizontal segment orthogonal to the rotation axis, which can be considered as the generating line of the helicoid in the direction plane.
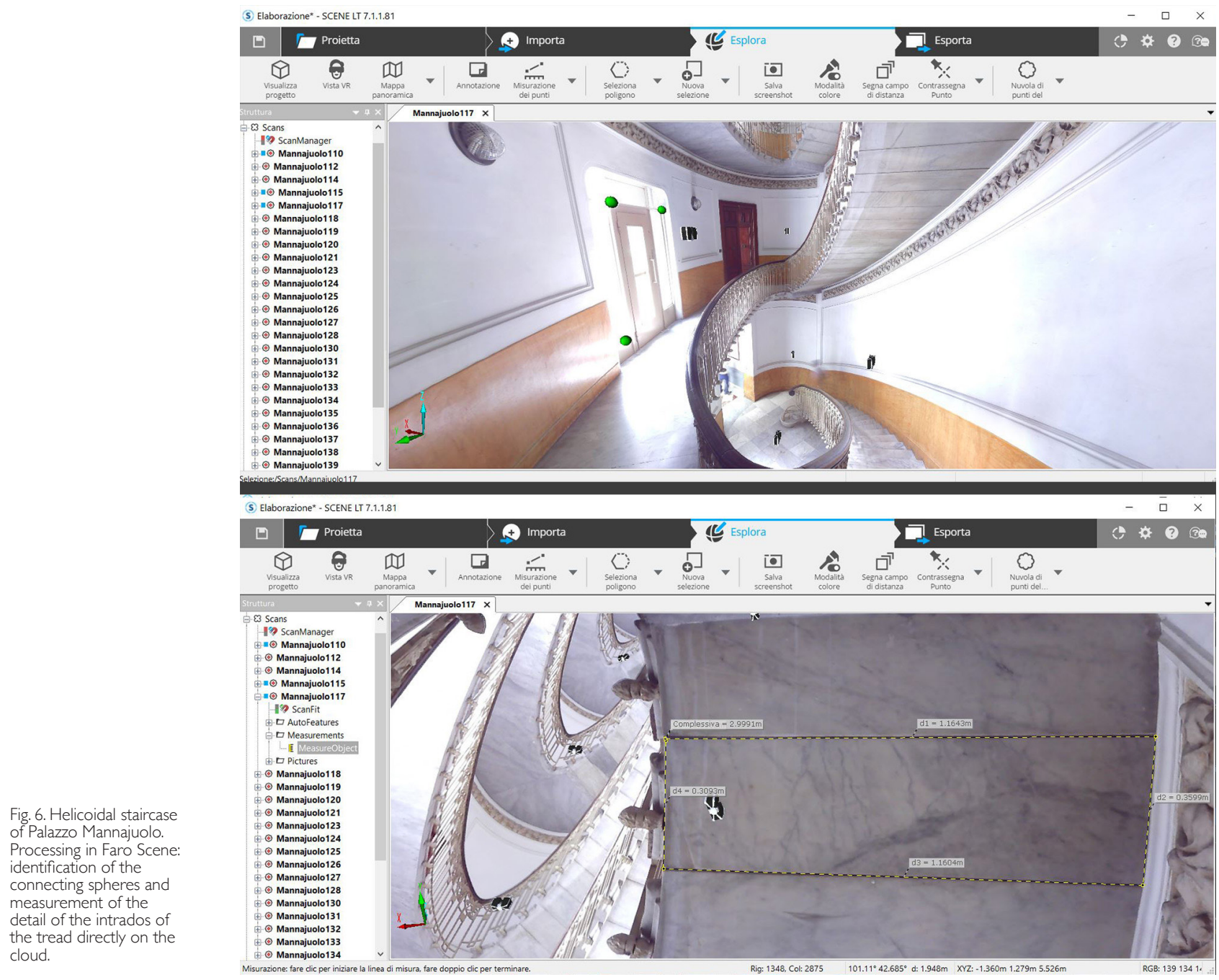

\section{A case study in the Neapolitan context}

This contribution refers to a survey campaign carried out in 2016, with the data obtained being reprocessed for the purpose of studying further compositional and constructive aspects [2]. In consideration of the particular spatial conformation and elements that make up the staircase of Palazzo Mannajuolo, it was decided to proceed with a 'reality-based' campaign. An active optical system was chosen by designing the path of the laser scanner stations so that the shadow areas were minimized as much as possible. Even if the staircase 
Fig. 7. Helicoidal staircase of Palazzo Mannajuolo. Axonometric exploded view of the laser scanner point cloud.

Fig. 8. Helicoidal staircase of Palazzo Mannajuolo. Analysis of the geometric composition of the plant.

Fig. 9. Helicoidal staircase of Palazzo Mannajuolo. Even if the ramps are

made up of 25 treads

each, the inter-storey

heights are all different

from each other.

Fig. 10. Helicoidal staircase of Palazzo Mannajuolo. Longitudinal section and cross section
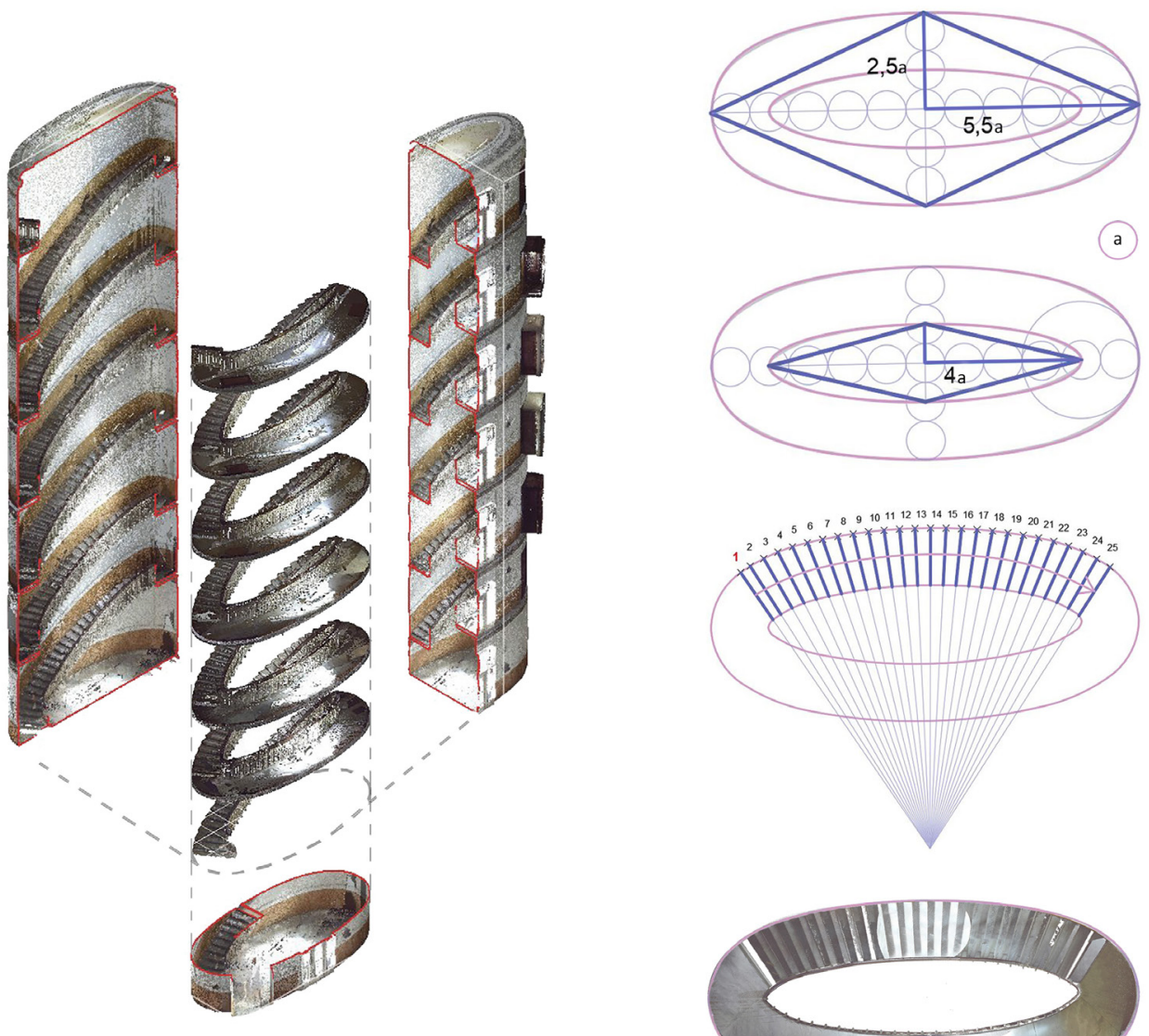

(a)
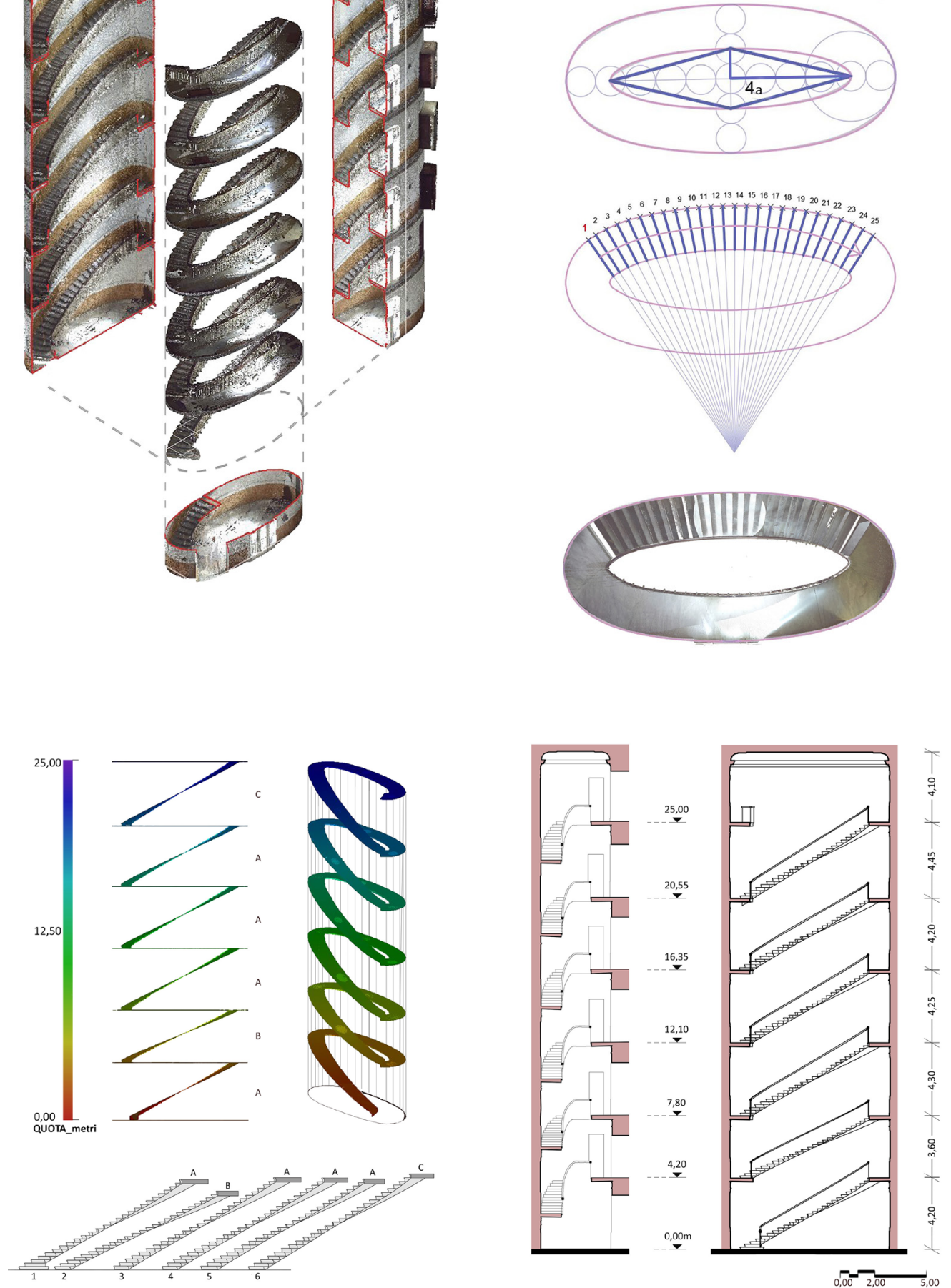
has a central shaft free from pillars and extends for all seven levels, it consists of ramps and landings protected by a cast iron railing worked with a floral motif typical of the liberty language. The number and position of the scans were therefore designed so that the projection of the railing would not disturb the acquisition of the risers and treads of the ramp.

The survey was carried out with a Faro Focus 3D s 120 laser scanner supplied by the TIR Laboratory of the Department of Architecture of the University of Naples Federico II. Twenty-seven scans were carried out with a pitch between the points of $6.136 \mathrm{~mm}$ at $10 \mathrm{~m}$. The station points were chosen by following the staircase from the bottom up. Two acquisitions were taken on the ground floor, three for each ramp (beginning, centre and end), one in the centre of each landing and one at the end of the last landing (for a better acquisition of the roof).

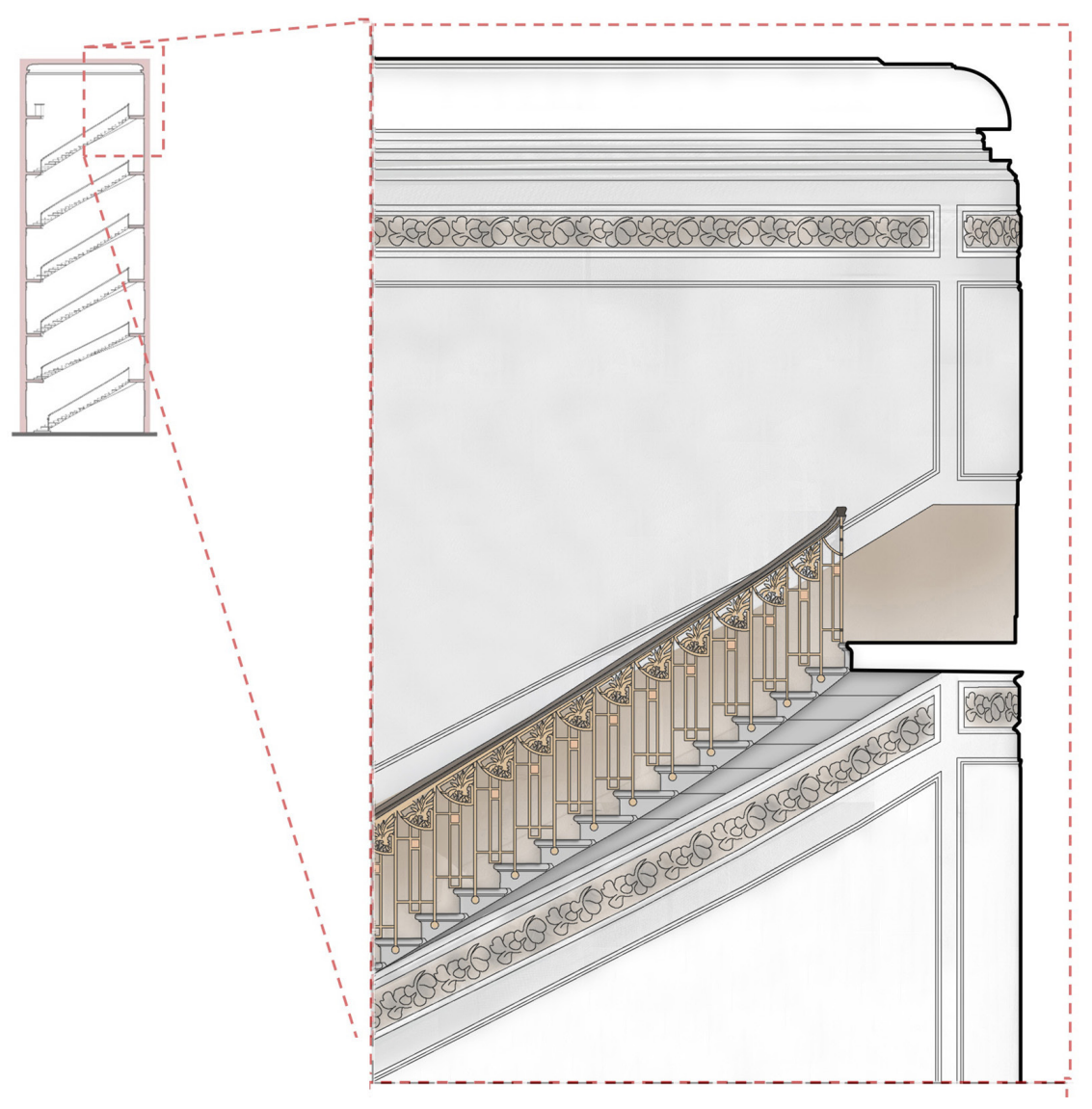

The post-processing phases were carried out with the Faro SCENE proprietary software, with spherical targets and checkerboard targets being distributed along the path to facilitate the alignment phases between the various scan positions (fig. 6).

The laser scanner survey campaign made it possible to obtain a three-dimensional digital clone of Arata's work in the form of a point cloud (fig. 7).

From the analysis of the data, a series of compositional ambiguities emerged that are not perceptible at first glance, which suggest some considerations in the relationship between the perceived and constructed realities.

From a first reading, the staircase consists of 6 flights alternating with landings that are repeated overlapping and apparently of the same size, describing the cylindrical stairwell characterised by an elliptical directing curve. The redrawing and acquisition of morphometric data obtained directly on the point cloud made the geometric references of the basic composition clearer, highlighting any consistencies and exceptions. 
The flat projection of the stairwell is characterised by the directing curve of the cylinder similar to an ellipse whose axes are in a 1 1:5 ratio. Analysing the shape, a proportional relationship between the two axes was found, identified by the repetition of a module indicated in Figure 8 with the letter a (fig. 8). The curve that draws the internal limit of the ramp and the landing can be obtained as an offset of the first ellipse, obtained as a consequence of the choice to keep the width of the ramps and landings equal to approximately $1.25 \mathrm{~m}$.

The distribution of the steps follows a radial geometry whose centre of rotation is identified along a vertical axis outside the cylinder. The segments that draw the treads in plan all converge towards a single centre and maintain a constant angular rotation equal to about $2.7^{\circ}$, except for the first tread which differs, albeit slightly, from the other tread widths, both with respect to the specific ramp to which it belongs, as well as with respect to the first treads of the other ramps.

An analysis of the 3D data showed how, although the ramps are all composed of 25 treads, the height of the inter-floor has a relative variation ranging from $10 \mathrm{~cm}$ to $85 \mathrm{~cm}$, only partly attributable to natural deformations and construction defects. At least three types of ramps with the same floor space and different elevation development can be identified, which are arranged vertically according to an A-B-A-A-A-C rhythm (fig. 9). The differences are found in relatively minimal variations between the risers of the individual steps, which in themselves are negligible but which on the whole make it possible to keep the number and size of treads constant (fig. I0).

The figurations created become an instrument through which to translate and interpret the characteristics and founding principles of the composition. These establish a connection between the real model and the graphic model, through which to express the cultural operations of the representation, which take place in an operation of synthesis between the signs and discretization of the physical reality (fig. II).

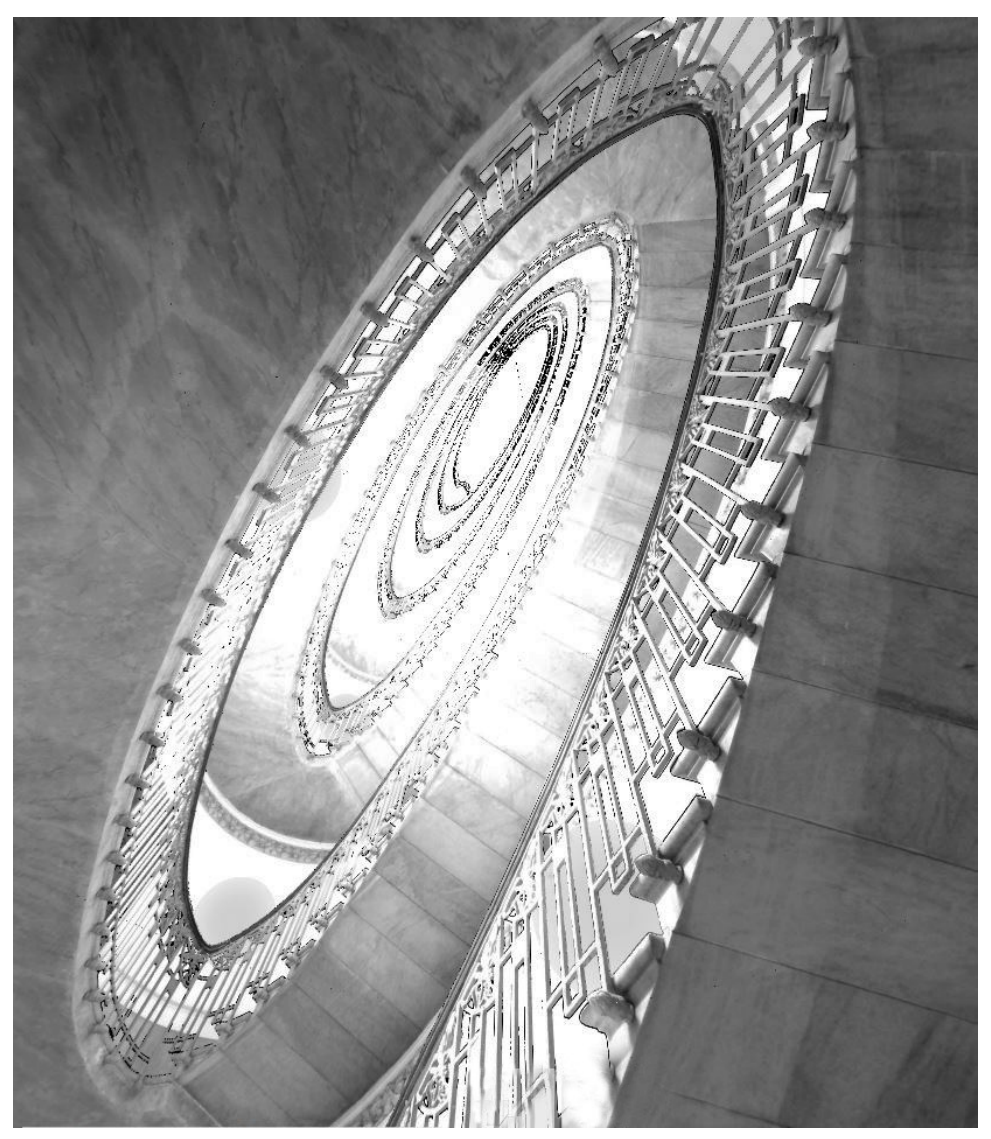




\section{Conclusions}

The staircase can be considered as an "always new archetype, an invariant that is continually renewed, a dynamic form through which the relationship between the qualities of time and the qualities of experience is realised" [Marcoaldi 20I5, p. I3]. The staircase of Palazzo Mannajuolo fully interprets this concept. An organism that manifests and enhances the lexical qualities of its time and proposes itself as an experiment capable of staging an experience that fully involves those who go through it. The staircase takes on a fundamental role, becoming the true protagonist of the architectural organism in which directional axes and upward forces are the tools through which to conceive the spatiality rich in suggestions and seductive solutions (fig. 12).

\section{Notes}

[I]The rebuilding of the building dates back to 1746, replacing the one that collapsed due to its antiquated conditions.

[2] The survey campaign was carried out by the architects Raffaele Catuogno, Simona Scandurra and Giulia Piccinin and resulted in the contribution of De Rosa A., D'Acunto G., Piccinin G. (2019). La vertigine dello sguardo: la scala elicoidale di Palazzo Mannajuolo In Anfione e Zeto n. 29, pp. I66-171.

\section{Reference}

Castagnaro A., Castiglione F. (2020). Giuseppe e Ugo Mannajuolo. Napoli: Editori Paparo.

Cirillo V. (20 I8). La rappresentazione della scala nella trattatistica italiana dal XVI al XVIII secolo. In diségno, vol. I, n. 3, pp. I77- 88. CirilloV., Zerlenga O. (2020). Entre arquitectura y geometría. Un ejemplo de escalera oval en la toba napolitana. In EGA Expresión Gráfica Arquitectónica, [S.I.], v. 25, n. 39, pp. 196-207.

De Fusco R. (1959). II floreale a Napoli. Napoli: Edizioni Scientifiche Italiane.

De Fusco R. (1994). Napoli nel Novecento. Napoli: Electa Napoli.

di Luggo A., Catuogno R., Paolillo A. (20I I). Palazzi Napoletani. Itinerari grafici e percorsi interpretativi nel rilievo dell'architettura. Napoli: Giannini Editore.

Gambardella A. (1974). Ferdinando Sanfelice architetto. Napoli.

Gravagnuolo B., Gravagnuolo G. (1990). Chiaia. Napoli: Electa Napoli.

Hogarth W. (200 I). L'analisi della Bellezza. Milano: Aesthetica.

Marcoaldi P. (20I5). 7 tipi di scale. La dimensione urbana della scala tra riti, spazialità e tempo. Roma: Aracne editrice.

Pezone M. G. (20I5). Geometria e arditezza tecnica nelle scale napoletane del Settecento a matrice poligonale. In G. Amirante, M. G. Pezone (a cura di). Tra Napoli e Spagna. Città storica architetti e architetture tra XVI e XVIII secolo. Napoli: Grimaldi Editore. Rosi R. (20 12). Palazzo Mannajuolo. Napoli: Paparo Edizioni.

Scalvini M. L., Mangone F. (1990). Arata a Napoli tra liberty e neoeclettismo. Napoli: Electa Editore.

Scamozzi V. (1615). Dell'idea dell'Architettura Universale, parte prima, libro terzo. Venezia.

Zerlenga O. (20 I7). Disegnare le ragioni dello spazio costruito. Le scale aperte del '700 napoletano. In diségno, n. I, pp. 45-56. Zevi B. (1994). Saper vedere l'architettura.Torino: Giulio Einaudi Editore.

\section{Authors}

Daniela Palomba, Università degli Studi di Napoli “Federico Il”, daniela.palomba@unina.it

Simona Scandurra, Università degli Studi di Napoli “Federico II", simona.scandurra@unina.it

To cite this chapter. Palomba Daniela, Scandurra Simona (202I). La linea curva che avvolge lo spazio/The curved line that envelops the space. In Arena A., Arena M., Mediati D., Raffa P. (a cura di). Connettere. Un disegno per annodare e tessere. Linguaggi Distanze Tecnologie. Atti del $42^{\circ} \mathrm{Conveg}$ no Internazionale dei Docenti delle Discipline della Rappresentazione/Connecting. Drawing for weaving relationship. Languages Distances Technologies. Proceedings of the $42^{\text {th }}$ International Conference of Representation Disciplines Teachers. Milano: FrancoAngeli, pp. 925-944. 